\title{
Chromosomal analyses in Megalonema platanum (Siluriformes: Pimelodidae), an endangered species from South American rivers
}

\author{
Rafael Augusto de Carvalho, ${ }^{1,5}$, Sebástian Sanchez², Ana Claudia Swarça ${ }^{3}$, Alberto Sergio \\ Fenocchio $^{4}$, Isabel C. Martins-Santos ${ }^{1}$ and Ana Lúcia Dias ${ }^{5}$
}

This study presents chromosomal data of Megalonema platanum from rio Tibagi, Paraná, Brazil and from rio Paraná, Argentina. The diploid number was equal 54 with karyotype composition of $24 m+16 s m+2 s t+12 a$ in both populations. The AgNOR sites were detected in the terminal position of a submetacentric pair of the two analyzed populations, coinciding with secondary constrictions on the short arm of pair 15. $\mathrm{CMA}_{3}$ and FISH with $18 \mathrm{~S}$ rDNA probe displayed fluorescent signals that correspond to the AgNOR sites and secondary constriction. The presence of a small acrocentric supernumerary chromosome can be observed in M. platanum from rio Tibagi, with centromeric heterochromatin. Others heterochromatic blocks were evidenced in the terminal position of some chromosome and one metacentric large chromosome pair, probably the first pair, showed an interstitial heterochromatin. In the population of the rio Paraná were still observed heterochromatic blocks in both ends in some chromosomes. This work brings for the first time cytogenetic date of M. platanum, which is a very rare species in the rio Paraná basin and may be endangered.

Este estudo apresenta dados cromossômicos de Megalonema platanum do rio Tibagi, Paraná, Brasil e do rio Paraná, Argentina. O número diploide foi igual 54 com composição cariotípica de $24 \mathrm{~m}+16 \mathrm{sm}+2 \mathrm{st}+12 \mathrm{a}$ em ambas populações. Os sítios AgNORs foram detectados na posição terminal de um par submetacêntrico das duas populações analisadas, coincidindo com constrição secundária no braço curto do par 15. $\mathrm{CMA}_{3}$ e FISH com sonda de DNAr 18S exibiram sinais fluorescentes que correspondem aos sítios AgNORs e à constrição secundária. A presença de um pequeno cromossomo supranumerário acrocêntrico foi observado em M. platanum do rio Tibagi, com heterocromatina centromérica. Outros blocos heterocromáticos foram evidenciados na posição terminal de alguns cromossomos e um par cromossômico submetacêntrico grande, provavelmente o primeiro par, mostrou heterocromatina intersticial. Na população do rio Paraná foram observados ainda blocos heterocromáticos em ambas regiões terminais em alguns cromossomos. Este trabalho mostra pela primeira vez dados citogenéticos de $M$. platanum, que é uma espécie muito rara na bacia do rio Paraná e pode estar ameaçada de extinção.

Key words: Cytogenetics, C-banding, $\mathrm{CMA}_{3}$, FISH, NORs, Pimelodidae.

\footnotetext{
'Departamento de Genética e Biologia Celular, CCB, Universidade Estadual de Maringá. Av. Colombo, 5790, 87020-900 Maringá, Paraná, Brazil.lumanu.carvalho@gmail.com,icmdsantos@uem.br

${ }^{2}$ Instituto de Ictiología del Nordeste. Facultad de Ciencias Veterinarias. Universidad Nacional del Nordeste. Sargento Cabral 2139,3400 Corrientes, Argentina.sanchez@vet.unne.edu.ar

${ }^{3}$ Departamento de Histologia, CCB, Universidade Estadual de Londrina. Caixa Postal 6001, 86051-970 Londrina, Paraná, Brazil. swarca@uel.br ${ }^{4}$ Universidad Nacional de Misiones. Departamento de Genética. Félix de Azara 1552, 3300, Posadas, Misiones, Argentina. afenocch@fceqyn.unam.edu.ar

${ }^{5}$ Departamento de Biologia Geral, CCB, Universidade Estadual de Londrina. Caixa Postal 6001, 86051-970 Londrina, Paraná, Brazil. anadias@uel.br
} 
The genus Megalonema Eigenmann, 1910 is endemic to South America, for which there are few biological data available. Lundberg \& Littmann (2003) defined six valid species of Megalonema: M. argentina (MacDonagh, 1938), M. pauciradiatum Eigenmann, 1919 and M. platanum (Günther, 1880) found in the rio Paraná basin; $M$. platycephalum Eigenmann, 1912 in the basins of the rios Amazonas, Essequibo and Orinoco; M. psammium Schultz, 1944 in the lago Maracaibo basin and M. xanthum Eigenmann, 1912 in the rio Magdalena basin. Recently Lundberg \& Dadhul (2008) described more two species: $M$. amaxanthum $\mathrm{n}$. sp. from the rio Amazonas basin and $M$. orixanthum n. sp. from the rio Orinoco basin. In $M$. platanum the body lacks clear and colored spots, with only the back of the head slightly darkened. The fins are clear, with the first ray of the pectoral ossified, and the snout is rounded and the eyes large (Lundberg \& Littmann, 2003).

The present study presents the first karyotype description of Megalonem platanum using AgNOR conventional,fluorochrome staining, in additions to $\mathrm{C}$-banding and fluorescence $i n$ situ hybridization (FISH) with 18S rDNA probe.

Twelve specimens of $M$. platanum were collected in distinct localities: 1) rio Tibagi, Paraná State, Brazil $\left(23^{\circ} 21^{\prime} 27.22^{\prime \prime S} 51^{\circ} 00^{\prime} 34.36^{\prime \prime} \mathrm{W}\right)$ (two males and two females); 2) río Paraná ( $28^{\circ} 57^{\prime} 30.72^{\prime}{ }^{\prime} \mathrm{S} 57^{\circ} 25^{\prime} 52.32^{\prime}$ 'W), from different localities in Argentina: Reconquista/Santa Fé (one male and two females), Corrientes/Corrientes (theree females), Yahapé/ Corrientes (one female) and Ita Ibaté/Corrientes (one female). The specimens of the rio Tibagi are deposited in Museu de Zoologia da Universidade Estadual de Londrina, voucher numbers MZUEL 1824 and of the rio Paraná are in Instituto de Ictiologia del Nordeste (Universidad Nacional del Nordeste, Argentina), voucher numbers INICNE 973, 1040, 1164, 1165, 1166, 1188, 1209, 1211. Mitotic chromosomes preparations were obtained according to Bertollo et al. (1978) and according to Foresti et al. (1993). Chromosomes were classified as metacentric (m), submetacentric (sm), subtelocentric (st) and acrocentric (a), according to Levan et al. (1964). NOR silver staining and C-banding were performed using the methods of Howell \& Black (1980) and Sumner (1972), respectively. A rDNA $18 \mathrm{~S}$ probe $(1700 \mathrm{pb})$ obtained from the nuclear DNA of the fish Oreochromis niloticus (Linnaeus, 1758) was used for in situ hybridization and was carried out as described by Swarça et al. (2001). This probe was marked with biotin-14dATP by nick translation (Gibco No. cat. 18247-015), according to the manufacturer's instructions. Chromomycin $\mathrm{A}_{3}\left(\mathrm{CMA}_{3}\right)$ staining followed Schweizer (1980).

The analysis of mitotic chromosomes of M. platanum showed a modal diploid number of 54 chromosomes in the two populations analyzed, with $24 \mathrm{~m}+16 \mathrm{sm}+2 \mathrm{st}+12 \mathrm{a}$ (Fig. 1a). In some metaphases examined, we found a pair of submetacentric chromosomes (pair 15) with a secondary constriction at the short arm in the terminal position (Fig. 1a). In a review on the cytogenetic studies of 27 species of the family Pimelodidae by Swarça et al. (2007), 23 had a diploid number of 56 chromosomes, three had $2 \mathrm{n}=50$ chromosomes: Pinirampus pirinampu (Spix \& Agassiz, 1829) (Swarça et al., 1999; Vasconcelos \& Martins-Santos, 2000), Luciopimelodus pati (Valenciennes, 1835) (Sánchez, 2006), and Calophysus macropterus (Liechtenstein, 1819) (Ramirez-Gil et al., 1998), and one had $2 \mathrm{n}=54$ chromosomes: Pimelodus fur (Lütken, 1874) (Garcia \& Moreira-Filho, 2005).

Three individuals of M. platanum from rio Tibagi showed the presence of an additional small acrocentric chromosome (Fig. 1a), indicating the occurrence of a supernumerary chromosomes. This chromosome was found to be present at a high intrapopulation frequency $(75 \%)$ and a low intraindividual frequency $(15.6 \%)$, where in a total of 96 metaphases examined in the population, only 15 had this small supernumerary chromosome. The absence of these chromosomes in the samples of lower rio Paraná basin suggested that these populations are isolated which should be confirmed through the analyses of additional specimens.

In Neotropical fishes, 61 species have supernumerary chromosomes or Bs, distributed in 16 families, 33 genera and seven different orders (Carvalho et al., 2008). These chromosomes in the family Pimelodidae were described in Bergiaria westermanni (Lütken, 1874) by Dias \& Foresti (1993), Iheringichthys labrosus (Lütken, 1874) by Vissotto et al. (1999), Carvalho et al. (2004), and Carvalho \& Dias (2005), Pimelodus ortmanni Haseman, 1911 and Pimelodus sp. NUP 690, NUP 1664, NUP 1786, NUP 1826 (NUP refers to the ichthyological collection of NUPELIA - Núcleo de Pesquisas em Limnologia, Ictiologia e Aquicultura, Universidade Estadual de Maringá) by Borin \& MartinsSantos (2004). The findings of the present study on $M$. platanum from rio Tibagi increases the number of species bearing supernumerary chromosomes to five for the family Pimelodidae, representing $8.2 \%$ of species carrying such chromosomes.

The C-banding technique allowed the detection in $M$. platanum of heterochromatic blocks in the terminal position of some chromosome pairs and a pair of large submetacentric chromosomes with interstitial heterochromatin in all populations (Fig. 1b, c). The individuals from rio Paraná also present some chromosomes with bands in both telomeric regions (Fig. 1c). C-banding for most of the family Pimelodidae is similar to that seen in $M$. platanum with some heterochromatic regions in the terminal position, as for example, in species of the genus Pimelodus (Souza et al., 2004; Garcia \& Moreira-Filho, 2005; Treco et al., 2008), Steindachneridion Eigenmann \& Eigenmann, 1919 (Swarça et al., 2005) and others. In several species and/or populations of the genus Pimelodus, chromosomal marker pairs, with interstitial heterochromatin, could also be seen (Borin \& Martins-Santos, 2004; Treco et al., 2008).

Supernumerary chromosomes are generally heterochromatic; however, in this work, the acrocentric B-chromosome of $M$. platanum showed heterochromatin only in the centromeric 


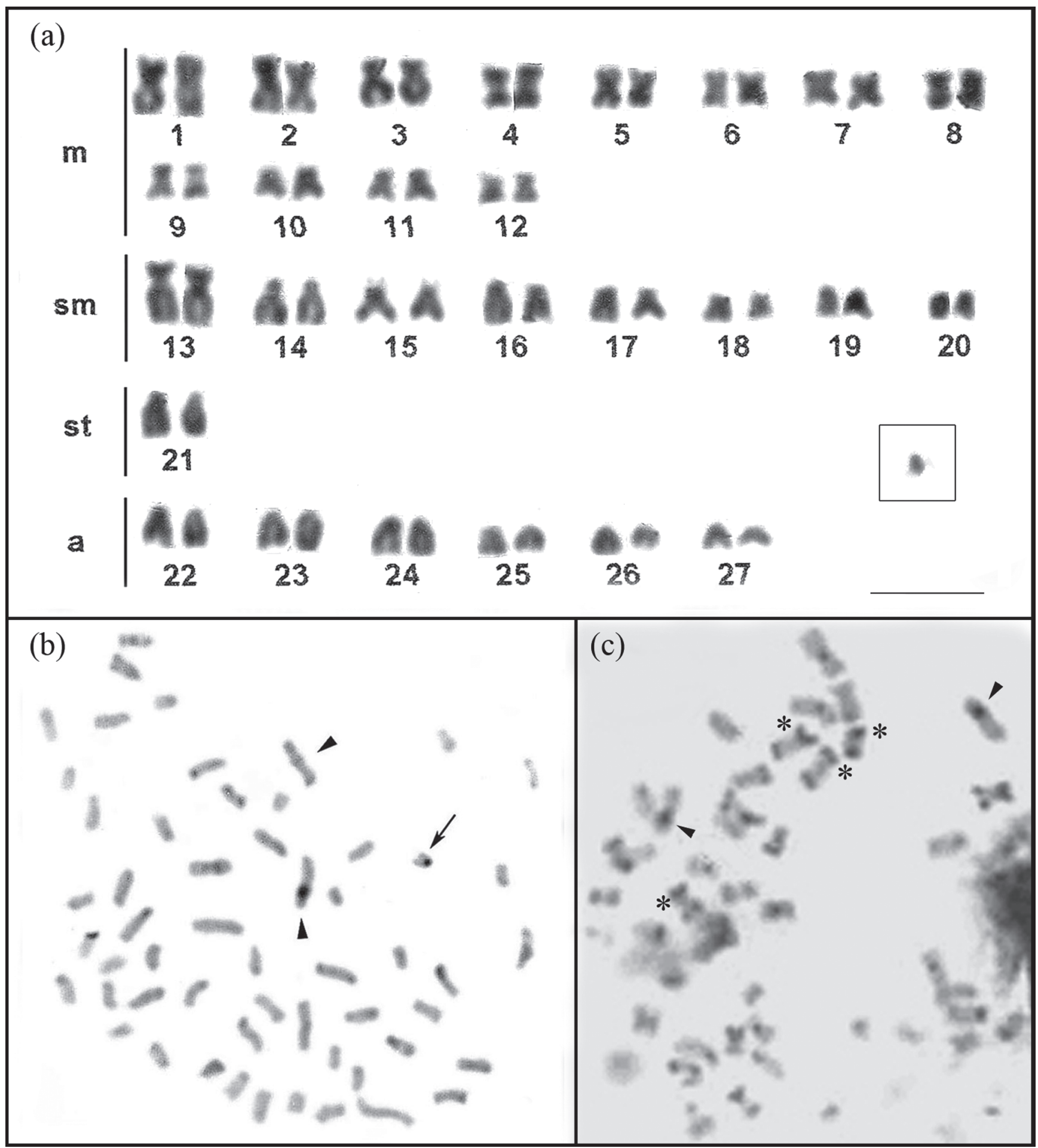

Fig. 1. Karyotype (a) and somatic metaphases of Megalonema platinum with C-banding (b) rio Tibagi and (c) rio Paraná. In the box the supernumerary chromosome. The arrowheads in (b) and (c) indicate the chromosome pair with interstitial heterochromatin; the arrow in (b) indicate the supernumerary chromosome partially heterochromatic and the asterisks in (c) indicate the chromosomes with heterochromatin blocks in both terminal regions. Scale bar $=10 \mu \mathrm{m}$

region, thus partially heterochromatic (Fig. 1b). Some species of the genus Rhamdia Bleeker, 1858, were shown to have partially heterochromatic B chromosomes (Abucarma \& Martins-Santos, 2001; Stivari \& Martins-Santos, 2004).
The AgNORs sites were detected in the terminal position of a submetacentric pair of the two analyzed populations, coinciding with secondary constrictions on the short arm of pair 15 (Fig. 2a). In some metaphases, only one silver-stained 


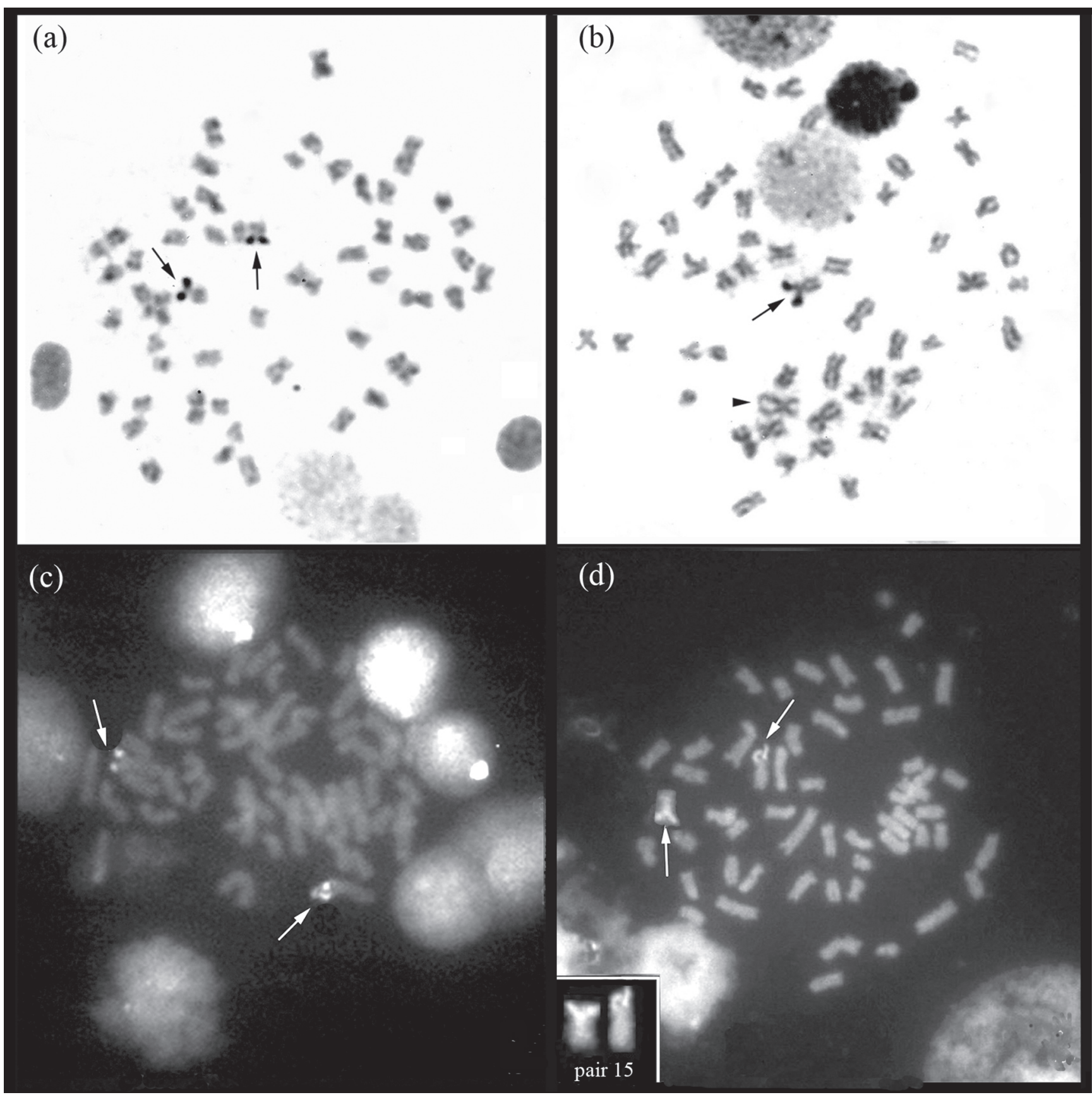

Fig. 2. Somatic metaphases of Megalonema platanum submitted to treatment with $\mathrm{AgNO}_{3}(\mathbf{a}$ and $\mathbf{b})$; FISH with $18 \mathrm{~S}$ rDNA probe $(\mathbf{c})$ and $\mathrm{CMA}_{3}(\mathbf{d})$. Arrows indicate the NOR bearing chromosomes. The arrowheads indicate the secondary constriction. Detail in (d) shows the chromosome pair $\mathrm{CMA}_{3}$ positive.

chromosome was observed, indicating an inactive NOR in one of the homologous chromosomes (Fig. 2b).

In situ hybridization with $18 \mathrm{~S}$ rDNA probe in M. platanum confirmed the NOR location in the secondary constriction of a pair 15 (Fig. 2c) as also observed in some Pimelodidae species by different authors: Souza et al. (2004), Carvalho \& Dias (2007), Swarça et al. (2008), Garcia \& Moreira Filho (2008).

$\mathrm{CMA}_{3}$ staining on chromosomes of $M$. platanum displayed fluorescent signals on the short arm of a pair of sm chromosomes (Fig. 2d), probably coinciding with the AgNOR, showing that this region of secondary constriction is rich in $\mathrm{GC}$ base pairs since the fluorochrome $\mathrm{CMA}_{3}$ preferably binds to chromatin segments rich in these base pairs. In these preparations, it was not possible to observe the supernumerary chromosome. In several species of fish, a positive correlation has been reported between of $\mathrm{CMA}_{3}$ sites and AgNORs (Garcia \& Moreira-Filho, 2005; Treco et al., 2008).

The data show that in terms of diploid number, $M$. platanum can be regarded as ancestral in relation to other species of Pimelodidae, and suggest that chromosomal 
rearrangements such as Robertsonian translocation or chromosomal fusion/fission are involved in the evolution of this group of fish. Thus, M. platanum must represent a primitive group within the family, with $2 n=54$ that is a feature rare and shared with Pseudopimelodidae that possibly is the sister group of Pimelodidae (Sullivan et al., 2006). Therefore $2 n=56$ and $2 n=50$, observed in other Pimelodidae species, could be derived karyotype characteristics. As for the microstructure, that is, number and location of the nucleolus organizer regions and the pattern of heterochromatin distribution, M. platanum has a more conservative character, even though individuals from rio Paraná present some peculiarities (i.e., heterochromatin in both telomeric regions).

\section{Acknowledgements}

Research supported by Fundação Araucária, CNPq and CAPES. The authors are grateful to Albert Leyva for assistance in the preparation of the manuscript and M.Sc. Larissa Bettin Pires and M.Sc. Marceléia Rubert for assistance in preparation of the photos.

\section{Literature Cited}

Abucarma, M. \& I. C. Martins-Santos. 2001. Karyotype and B chromosome of Rhamdia species (Pisces, Pimelodidae) endemic in the river Iguaçu basin. Cytologia, 66: 299-306.

Bertollo, L. A. C., C. Takahashi \& O. Moreira-Filho. 1978. Cytotaxonomic considerations on Hoplias lacerdae (Pisces, Erythrinidae). Brazilian Journal of Genetics, 1: 103-120.

Borin, L. A. \& I. C. Martins-Santos. 2004. Study on karyotype and occurrence of B chromosomes in two endemic species of the genus Pimelodus (Siluriformes, Pimelodidae) from the River Iguaçu. Hereditas, 140: 201-209.

Carvalho, R. \& A. L. Dias. 2005. Cytogenetic characterization of B chromosomes in two populations of Iheringichthys labrosus (Pisces, Pimelodidae) from the Capivara Reservoir (Paraná, Brazil). Caryologia, 58: 269-273.

Carvalho, R. \& A. L. Dias. 2007. Interindividual size heteromorphism of NOR and chromosomal location of 5S rRNA genes in Iheringichthys labrosus. Brazilian Archives of Biology and Technology, 50: 141-146.

Carvalho, R., I. C. Martins-Santos \& A. L. Dias. 2008. Bchromosomes: an update about their occurrence in freshwater Neotropical fishes (Teleostei). Journal of Fish Biology, 72: 19071932.

Dias, A. L. \& F. Foresti. 1993. Cytogenetic studies on fishes of the family Pimelodidae (Siluroidei). Brazilian Journal of Genetics, 6: 585-600.

Foresti, F., C. Oliveira \& L. F. Almeida Toledo. 1993. A method for chromosomes preparations from large fish specimens using "in vitro" short-term treatment with colchicine. Experientia, 49: 810-814.

Howell, W. M. \& D. A. Black. 1980. Controlled silver staining of nucleolus organizer regions with a protective colloidal developer: a one step method. Experientia, 36: 1014-1015.
Garcia, C. \& O. Moreira-Filho. 2005. Cytogenetical analyses in three fish species of the genus Pimelodus (Siluriformes: Pimelodidae) from rio São Francisco: considerations about the karyotypical evolution in the genus. Neotropical Ichthyology, 3: 285-290.

Garcia, C. \& O. Moreira-Filho. 2008. Localization of ribosomal genes in three Pimelodus species (Siluriformes, Pimelodidae) of the São Francisco River: 5S genes as species markers and conservation of the 18S rDNA sites. Genetics and Molecular Biology, 31: 261-264.

Levan, A., K. Fredga \& A. A. Sandberg. 1964. Nomenclature for centromeric position on chromosomes. Hereditas, 52: 201220.

Lundberg, J. G. \& W. M. Dahdul. 2008. Two new cis-Andean species of the South American catfish genus Megalonema allied to transAndean Megalonema xanthum, with description of a new subgenus (Siluriformes: Pimelodidae). Neotropical Ichthyology, 6(3): 439-454.

Lundberg, J. G. \& M. W. Littmannn. 2003. Pimelodidae. In: Reis, R. E., S. O. Kullander \& C. J. Ferraris, Jr. (Eds.). Check list of the freshwater fishes of South and Central America. Porto Alegre, Edipucrs, 729p.

Ramirez-Gil, H., E. Feldberg, V. M. F. Almeida-Val \& A. L. Val. 1998. Karyological, biochemical, and physiological aspects of Callophysus macropterus (Siluriformes, Pimelodidae) from the Solimões and Negro rivers (Central Amazon). Brazilian Journal Medic Biology Research, 31: 1449-1458.

Schweizer, D. 1980. Simultaneous fluorescent staining of $R$ bands and specific heterochromatic regions (DA-DAPI bands) in human chromosomes. Cytogenetics and Cell Genetics, 27: 190-193.

Souza, L., L. Giuliano-Caetano \& A. L. Dias. 2004. Banding chromosome pattern of two species of Pimelodus (Siluriformes, Pimelodidae) from the Paraná river basin of Brazil. Folia Biologica, 52: 165-169.

Stivari, M. K. \& I. C. Martins-Santos. 2004. Karyotype diversity in two populations of Rhamdia quelen (Pisces, Heptapteridae). Cytologia, 69: 25-34.

Sullivan, J. P., J. G. Lundberg \& M. Hardman. 2006. A phylogenetic analysis of the major groups of catfishes (Teleostei, Siluriformes) using rag1 and rag2 nuclear gene sequences. Molecular Phylogenetics Evolution, 41: 636-662.

Sumner, A. T. 1972. A simple technique for demonstrating centromeric heterochromatin. Experimental Cell Research, 75: 304-306.

Swarça, A. C., M. M. Cestari, L. Giuliano-Caetano \& A. L. Dias. 2001. Cytogenetic characterization of the large South American siluriform fish species Zungaro zungaro (Pisces, Pimelodidae). Chromosome Science, 5: 51-55.

Swarça, A. C., L. Giuliano-Caetano \& A. L. Dias. 1999. Cytogenetic characterization through chromosomic banding of Pinirampus pirinampu (Pisces, Pimelodidae) from the Tibagi river basin PR/Brazil. Caryologia, 52: 31-35.

Swarça, A. C., A. S. Fenocchio \& A. L. Dias. 2007. An update cytogenetic review for species of the families Pseudopimelodidae, Pimelodidae and Heptapteridae (Pisces, Siluriformes). Suggestion of a cytotaxonomical classification. Caryologia, 60: 338-348.

Swarça, A. C., A. S. Fenocchio, M. M. Cestari \& A. L. Dias. 2008. Analyses of the structure of NORs in two species of South American Sorubiminae fishes (Siluriformes) by means of several cytogenetic techniques. Folia Biologica, 56: 31-35. 
Treco, F. R., L. R. Malabarba, L. Giuliano-Caetano \& A. L. Dias. 2008. Cytogenetic study of two species of the family Pimelodidae (Siluriformes) collected in lago Guaíba, Rio Grande do Sul, Brazil. Neotropical Ichthyology, 6: 87-92.

Vasconcelos, C. \& I. C. Martins-Santos. 2000. Chromosome polymorphism in species of the Pimelodidae family (Pisces, Siluriformes). Hereditas, 132: 103-109.

Vissotto, P. C., F. Foresti \& C. Oliveira. 1999. Supernumerary chromosomes in two species of the family Pimelodidae (Teleostei, Siluriformes). Chromosome Science, 3: 9-13.

Accepted December 5, 2010 Published March 31, 2011 